\title{
Gamma-Aminobutyric Acid Receptor Binding
}

National Cancer Institute

\section{Source}

National Cancer Institute. Gamma-Aminobutyric Acid Receptor Binding. NCI Thesaurus. Code C40504.

A process that involves the binding of gamma-aminobutyric acid to a GABA A receptor.

These interactions are involved in inhibition of neurotransmission. 